\title{
ANALYSIS OF GEOPHYSICAL LOGS
}

FROM THE

HAWAII GEOTHERMAL PROJECT WELL

\author{
Albert J. Rudman \\ Indiana University \\ Bloomington, Indiana
}

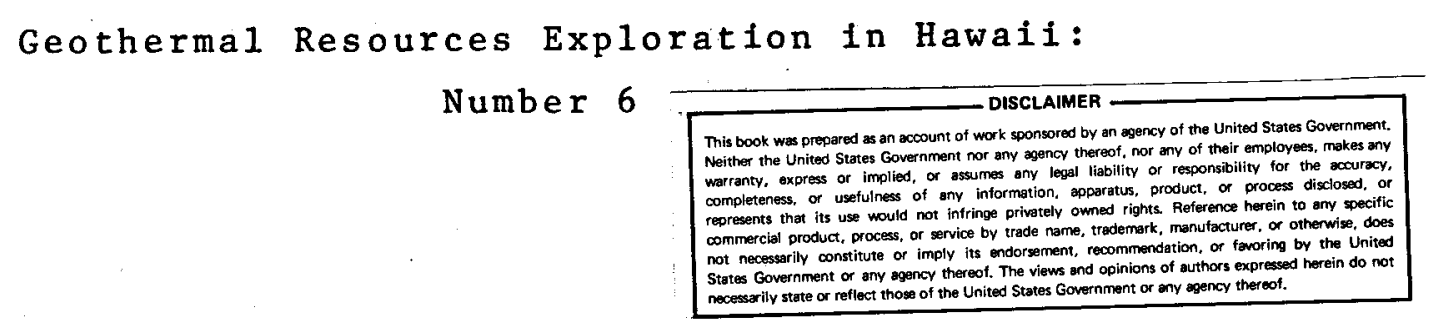

September 1978

Prepared for

NATIONAL SCIENCE FOUNDATION, Grant GI-38319

and

ENERGY RESEARCH AND DEVELOPMENT AGENCY, Grant EY-76-C-03-1093

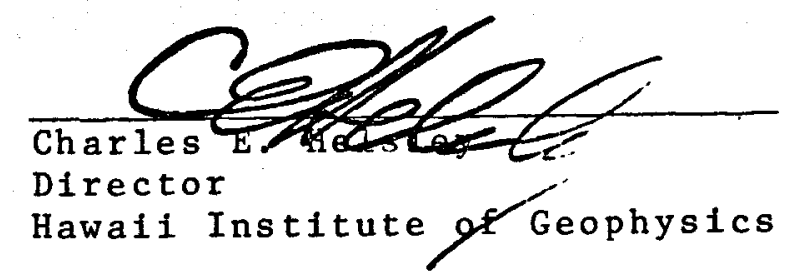




\section{DISCLAIMER}

This report was prepared as an account of work sponsored by an agency of the United States Government. Neither the United States Government nor any agency Thereof, nor any of their employees, makes any warranty, express or implied, or assumes any legal liability or responsibility for the accuracy, completeness, or usefulness of any information, apparatus, product, or process disclosed, or represents that its use would not infringe privately owned rights. Reference herein to any specific commercial product, process, or service by trade name, trademark, manufacturer, or otherwise does not necessarily constitute or imply its endorsement, recommendation, or favoring by the United States Government or any agency thereof. The views and opinions of authors expressed herein do not necessarily state or reflect those of the United States Government or any agency thereof. 


\section{DISCLAIMER}

Portions of this document may be illegible in electronic image products. Images are produced from the best available original document. 


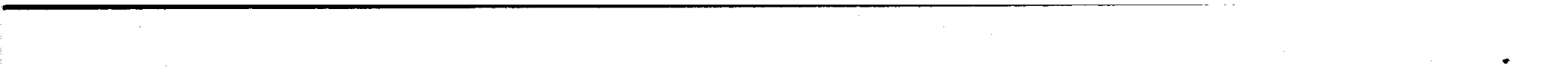


A 6445-foot test we11 was completed on April 27, 1976 in the Puna Area of Hawail as part of an extensive project to investigate a geothermal reservoir for energy production. Because bottom hole temperatures exceeded $300^{\circ} \mathrm{C}$, it was possible to run geophysical logs in the upper 3500 feet only.

Study of conventional and induction resistivity, self potential, neutron, gamma ray, caliper, temperature, temperature differential and drilling rate logs show that porosity, permeability and fluid flow are qualitatively identified on the logs. Lithologic logs of sample cuttings taken at five- to ten-foot intervals (together with cores taken at approximately 700-foot intervals) substantiate preliminary findings of the porous and permeable zones. Although the logs investigated are above many of the zones of production, new information was obtained about the in-situ nature of permeability in Hawailan basalts. 


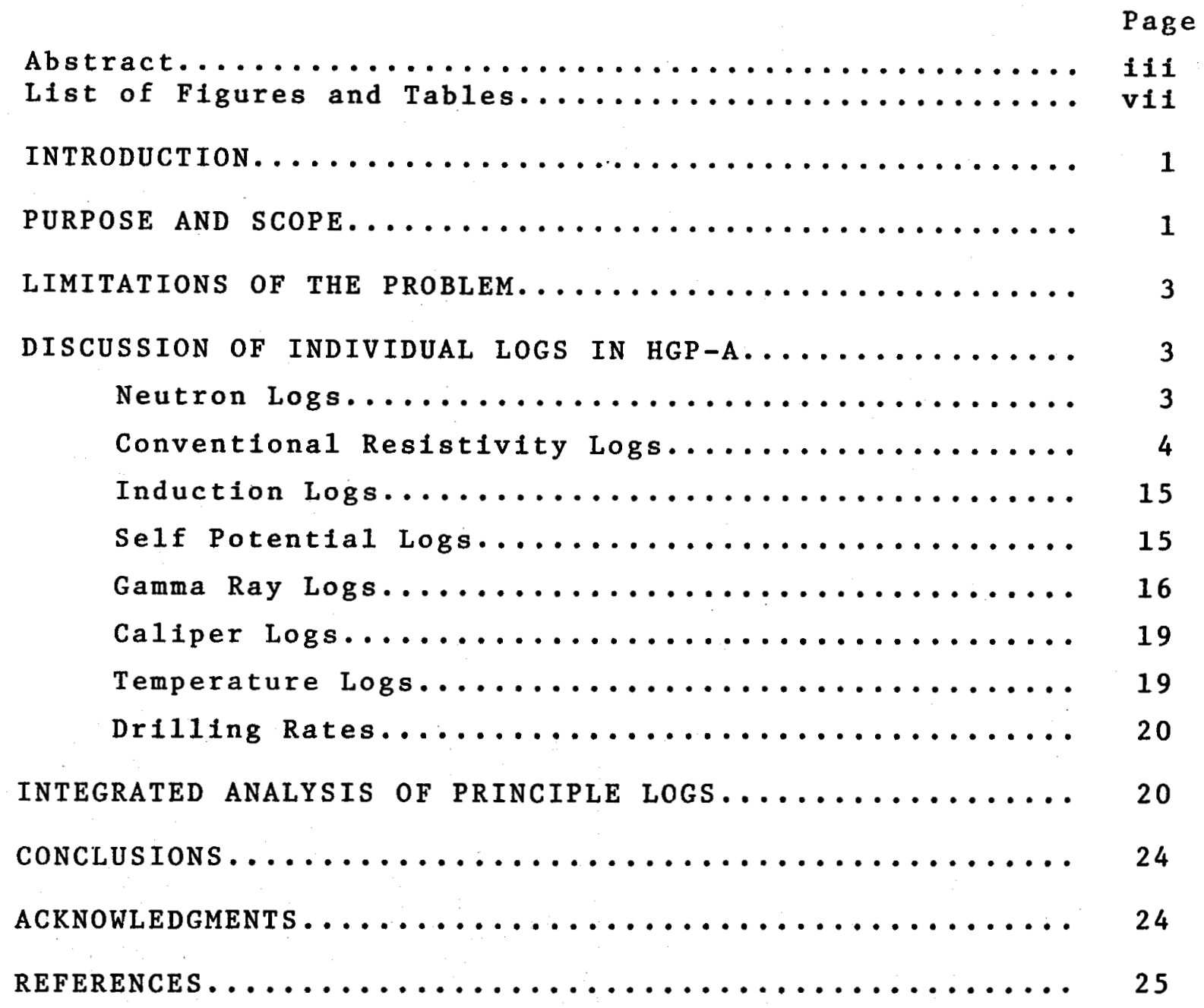


1. Gamma ray, neutron and differential temperature logs

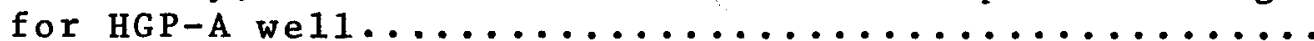

2. Lithologic column for HGP-A we 11 based on macro and microscopic studies of sample cuttings by Daniel B.

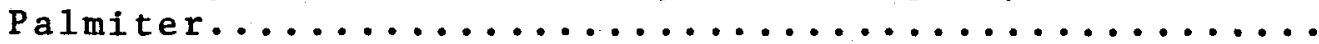

3. Lithologic column, drilling rate and volume percentages for a portion of the HGP-A well based on macro and microscopic studies of sample cuttings by Daniel B. Palmiter.......................

4. Geophysical logs from 2220 to 3450 feet (in uncased

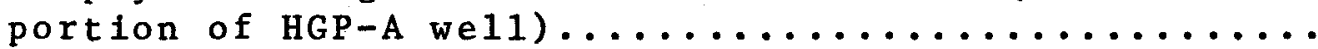

5. Continuous temperature $\operatorname{logs}$ and temperature differentials for two separate runs at 12 hour intervals...

6. Kuster Thermograph for four separate runs.........

7. HGP-A drilling rate in feet per hour for the 2000-

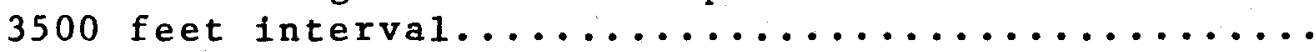

8. Geophysical logs used for integrated analysis of porous and permeable zones and fluid flows from 3000

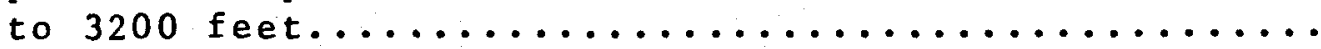

9. Geophysical logs used for integrated analysis of permeable zones and fluid flows from 3300 to 3400

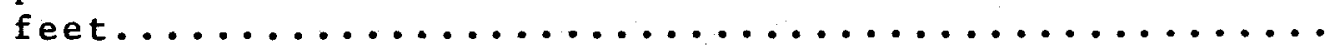

Table

1. Summary of available $10 \mathrm{~g}$ data from HGP-A we11......

2. Relationship of HGP-A neutron log count to geology

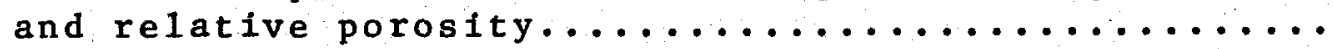

3. Relationship of HGP-A conventional resistivity logs

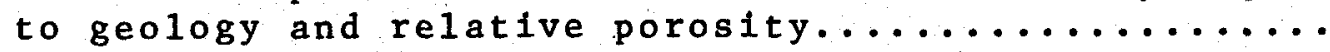

4. Relationship of HGP-A self potential logs to possible zones of relative permeability. Analysis is based on correlation 11 thologies (FIgures 2 and 3 ) and SP logs

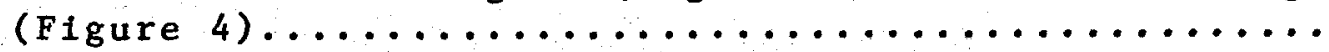

5. Relationship of HGP-A gamma ray log count to possible zones of relative permeability. Analysis is based on correlation of 1ithologies (Figures 2 and 3 ) and gamma ray and neutron logs (Figures 1 and 4 )........ 


\section{INTRODUCTION}

The Hawa11 Geothermal Project (HGP) was established in 1972 with funds allocated by the state and county of Hawail, and the National Science Foundation (ERDA). Phase I was primarily a Geological and Geophysical program with supporting studies on engineering, environment and drilifng developments. Major emphasis in Phase $I$ was on geophysical surveys to study whether and where geothermal sources existed on the island of Hawail. Field studies began in May 1973 taking aerial photogeology, surface resistivity, electromagnetic and microseismic data.

In May 1975, a Research Drilling Program (Phase II) was established on a site near the east rift of Kilauea in the Puna District. Geophysical surveys were continued during Phase II and technical reports were written on gravity profiles, total field magnetics, well temperatures, seismology, hydrology, physical properties of rocks, geoelectric and geochemical surveys (Klein and Kauahikaua, 1975 ; Furumoto et a1., 1977; Ke11er et a1., 1977; Kroopnick et a1., 1978).

Complete summaries of the HGP up to July 1977 are presented in four progress reports entitled: Hawail Geothermal Project Summary Report for Phase I (May, 1976), Initial Phase II Progress Report (February, 1976), Phase III - Well Testing and Analyses (January, 1977) and (July, 1977). On Apri1 27, 1976, the HGP-A we11 was completed to a depth of 6,445 feet and casing set from surface to a depth of 2,220 feet.

\section{PURPOSE AND SCOPE}

Geophysical logs were run by Gearhart-0wens Company and a summary of data is presented as Table 1. According to 1ithologic studies of the cores and samples (D. Palmiter, personal communication, 1976), the basaltic flows in the HGP-A well show significant changes in textures and fracture patterns. - Rocks vary from glassy to crystalline to vesicular and from cinder and clinker units to all degrees of fracturing. It is the purpose of this study to demonstrate whether $10 \mathrm{~g}$ data can be used to identify variations in porosity and permeability associated with changes in rock textures and to recognize fluid flow. It 
Table 1. Summary of available log data from HGP-A we11

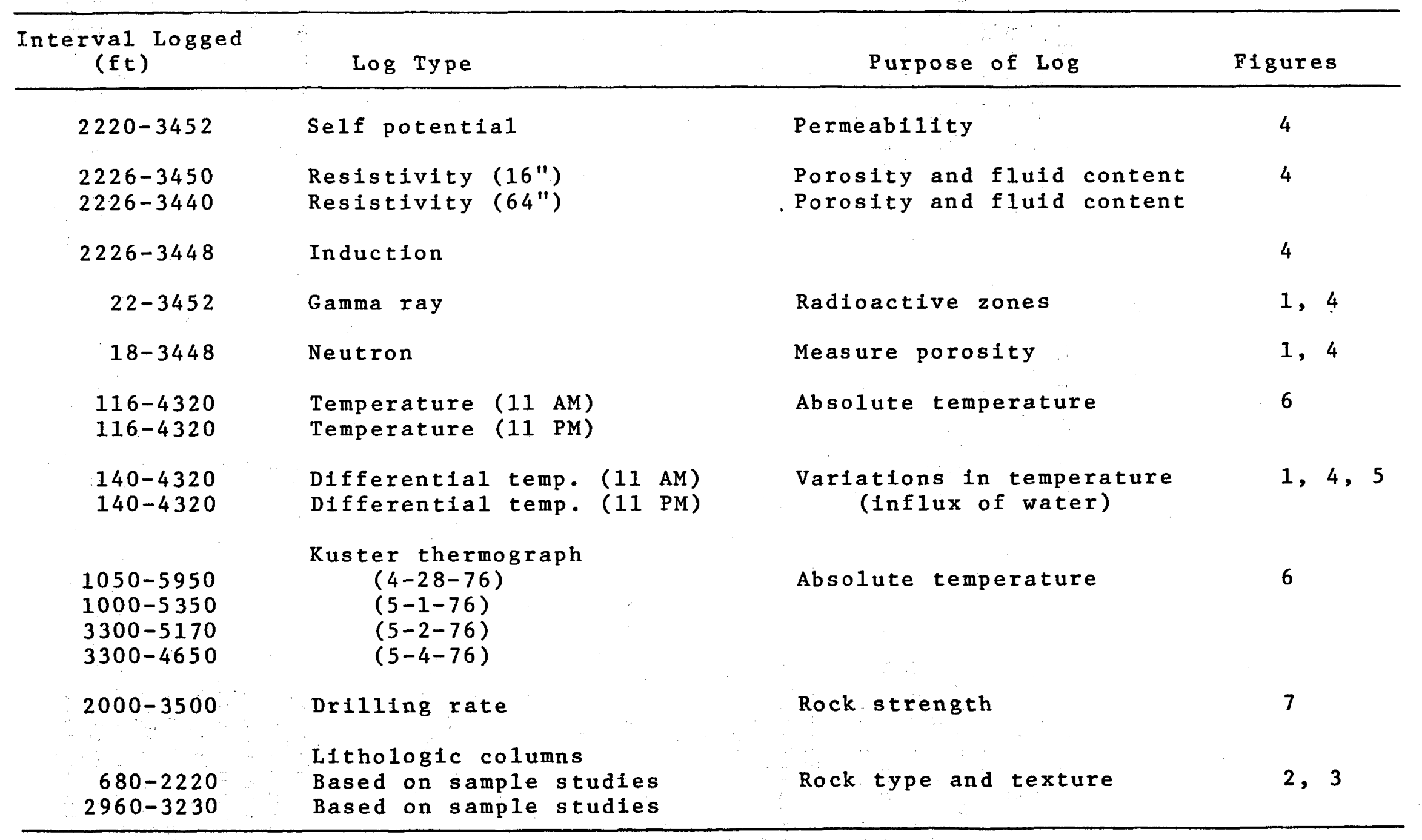


Is not within the scope of this report to quantitatively evaluate the degree of porosity or the extent of fluid flow--those aspects remain for future work when data about the physical properties of the cores are interpreted.

\section{LIMITATIONS OF THE PROBLEM}

The HGP-A well has recorded bottom hole temperatures exceeding the required $300^{\circ} \mathrm{C}$ necessary for geothermal energy. It is one of the hottest geothermal wells known, with temperatures as high as $357^{\circ} \mathrm{C}$. Upon completion of the well, downhole testing of temperature and pressure while the well was discharging steam established the presence of sufficient porosity, permeability, and fluid flow near the bottom. Excellent production zones may also exist between 2,500 and 5,000 feet. Unfortunnately, conventional logging cannot operate at temperatures exceeding $150^{\circ} \mathrm{C}$. Therefore the logs discussed in this report reach only 3,500 feet, well above much of the zone of possible production. Nevertheless, analysis of these logs is vital for our understanding of in-situ variations of porosity and permeability in Hawaiian basalts. Because little is known about logging interpretation in these rocks, this study is considered a preliminary report.

\section{DISCUSSION OF INDIVIDUAL LOGS IN HGP-A WELL}

In the following sections, logs recorded in the HGP-A well are described in detall. The overall format will be to present (1) a brief summary of principles (Schlumberger, $1969 \mathrm{a}, \mathrm{b}$ ), (2) a table summarizing characteristic values observed on the $10 g$, and (3) a concluding paragraph to interpret broad relationships of the log to porosity and permeability.

The summary statement at the end of this report attempts to interrelate a11 of the logs into a single coherent interpretation.

\section{Neutron Logs}

Principles. A neutron $10 \mathrm{~g}$ measures the amount of hydrogen present in a formation. If water concentration (or porosity) is high, neutrons emitted from a radioactive source in the sonde are slowed down and captured. Thus a decreased counting rate at the detector indicates a high porosity rock within a foot radius of the hole. Conversely, an increased count signifies a decreased porosity (or hydrogen concentration). However, absolute values of porosity are obtainable from a neutron $10 \mathrm{~g}$ only if the sonde and radioactive source are calibrated as a system (usually in terms of API neutron units). 
In this study, the neutron $10 \mathrm{~g}$ was not calibrated and only relative measures of porosity are meaningful. Porosities in the HGP-A well probably average only a few percent, but previous studies of neutron logs from 0ahu (Peterson, 1974; Peterson and Segal, 1974) show that a wide range of values are possible. For example, porosities of $5 \%$ were observed in dense flows, $50 \%$ in a clinker zones and $100 \%$ opposite cavities. Murli Manghnani (Hawail Institute of Geophysics) is presently investigating the nature of porosity in cores from the HGP-A well and such data should be useful in quantitatively calibrating the neutron log for porosities. In general, aboveaverage porosity is associated with vesicular units, clinker and cinder zones and sometimes highly fractured units. The opposite is not always true; high porosity zones are not necessarily permeable. Certain dense zones may be highly permeable through the mechanism of fracturing.

The neutron logging system used in the HGP-A well recorded gamma ray, neutron and casing collar logs simultaneously. An overall summary of the neutron $10 \mathrm{~g}$ is given in $T a b 1 e$ and 2 s based on a study of the log (Figures 1 and 4) and of lithologic columns (Figures 2 and 3 ). The casing collar log is of interest to the production engineer and is not treated in this report.

Interpretation. The neutron $10 \mathrm{~g}$ is an excellent indicator of porosity. Average values in the region of well casing (to 2,220 feet) are about 250 API units; below that, about 500 API. Although the $\log$ is not calibrated, a count of 500 is considered typical for dense, low porosity Hawalian basalts (Chester Lao, personal communication). The count below 3,000 feet tends to be higher. This correlates well with the temperature log (Figure 6) which shows a constant temperature gradient of $0.12^{\circ} \mathrm{C} / \mathrm{ft}$ from 3,000 feet to 4,400 feet. It may indicate that the section below 3,000 feet is low in bulk porosity and permeability and that the major form of heat transfer is by conduction rather than convection.

Table 2 identifies several zones of high neutron count (600) as extremely dense flows that are of special interest. It is above and below these dense units that cinder and clinker zones with high permeability may exist. In addition, the chilled margins of these dense flows may contain fractures associated with favorable permeability.

\section{Conventional Resistivity Logs}

Principles. Resistivity in ohm-meters is a measure of a formation's ability to impede the flow of current. In conventional logs, potential differences are measured at instrument spacings of 16 inches (short normal) and 64 inches (medium normal). The longer the spacing, the deeper the penetration. 

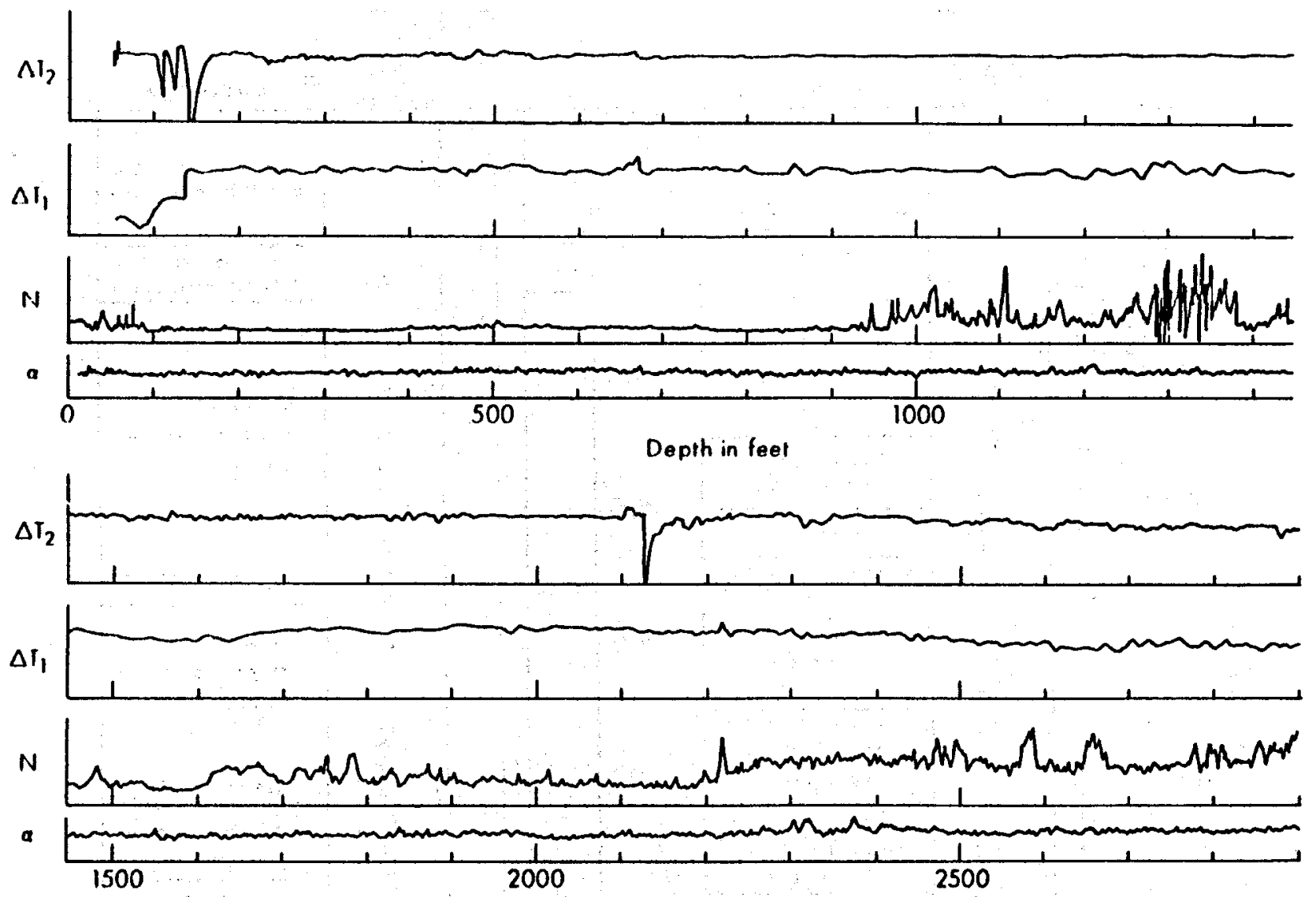

\section{Depth in feet}
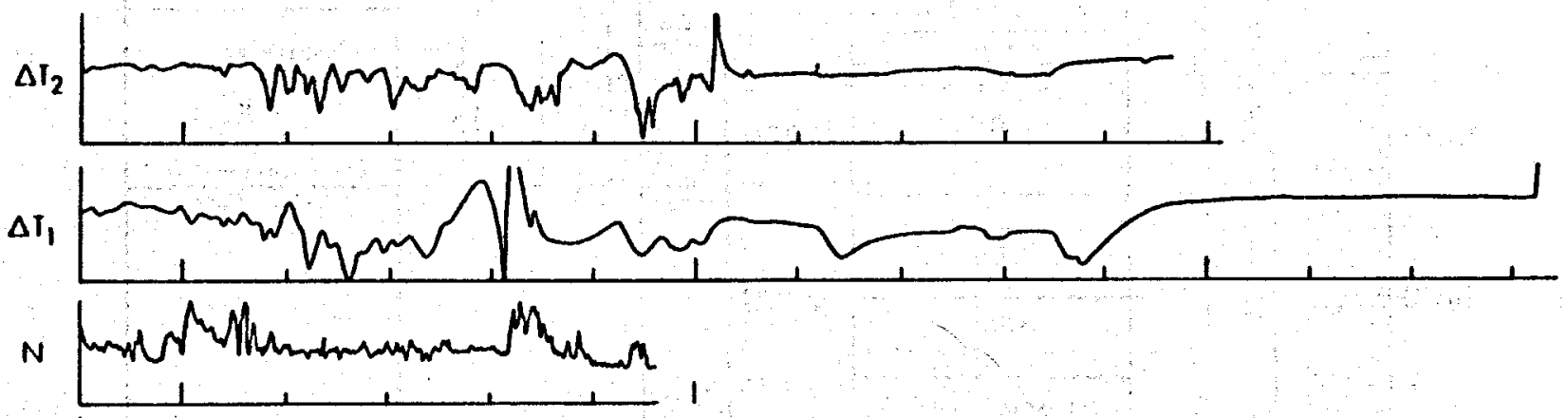

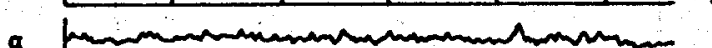

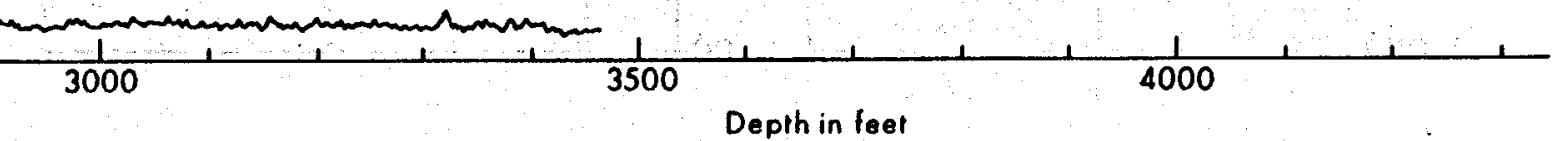

Figure 1. Gamma ray $(\gamma)$, neutron $(N)$ and differential temperature logs $(\Delta \mathrm{T})$ from $H G P-A$ well. $\Delta T_{1}$ and $\Delta T_{2}$ were run on 04-25-76 at 1100 and 2300 hours, respectively. Logs are continued on the next two pages. 


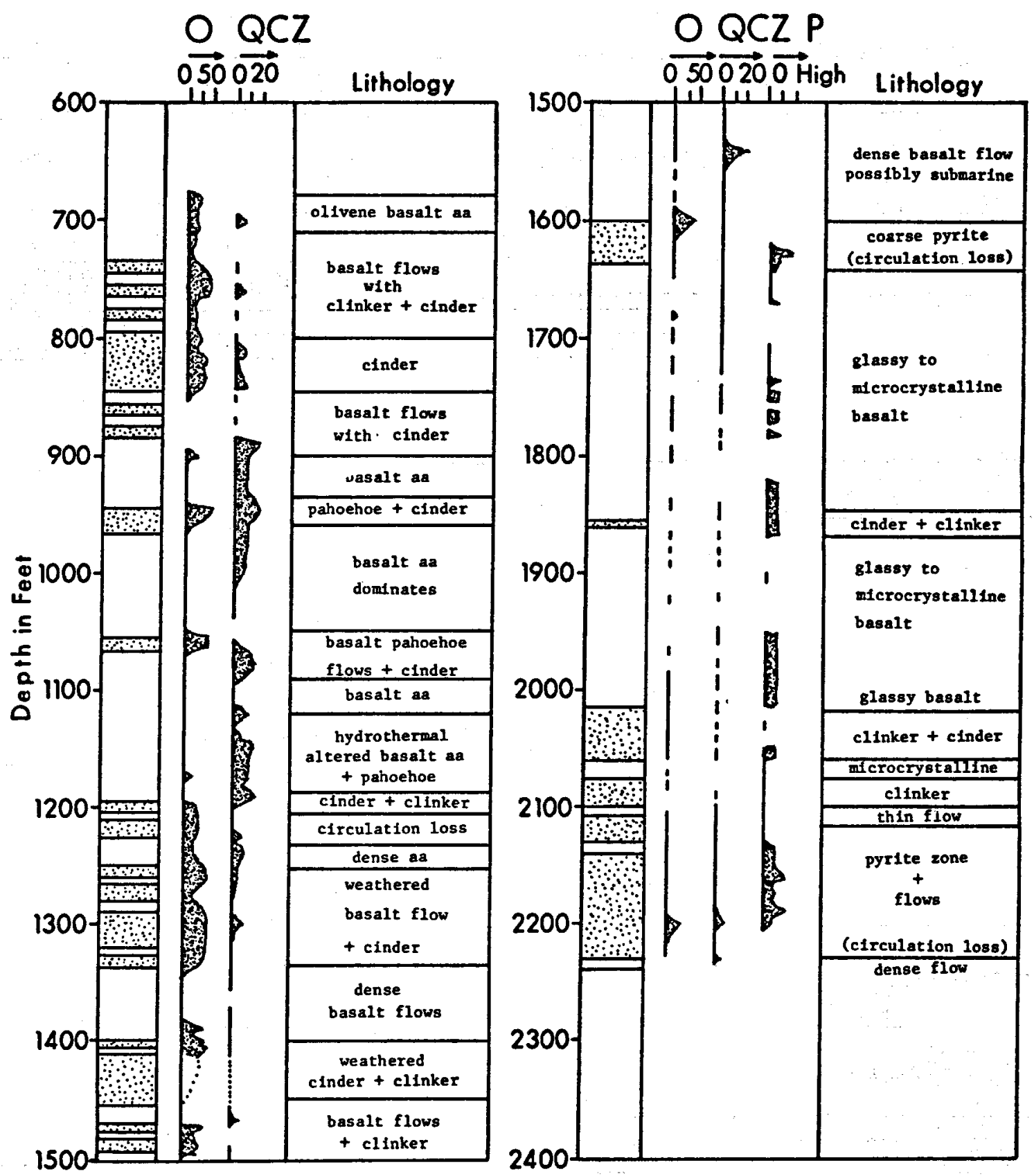

Figure 2. Lithologic column for HGP-A well based on macro- and microscopic studies of sample cuttings by Daniel B. Palmiter (Hawail Institute of Geophysics). 0 (percent oxidation), QCZ (percent quartz, calcite, zeolite), $P$ (pyrite). 


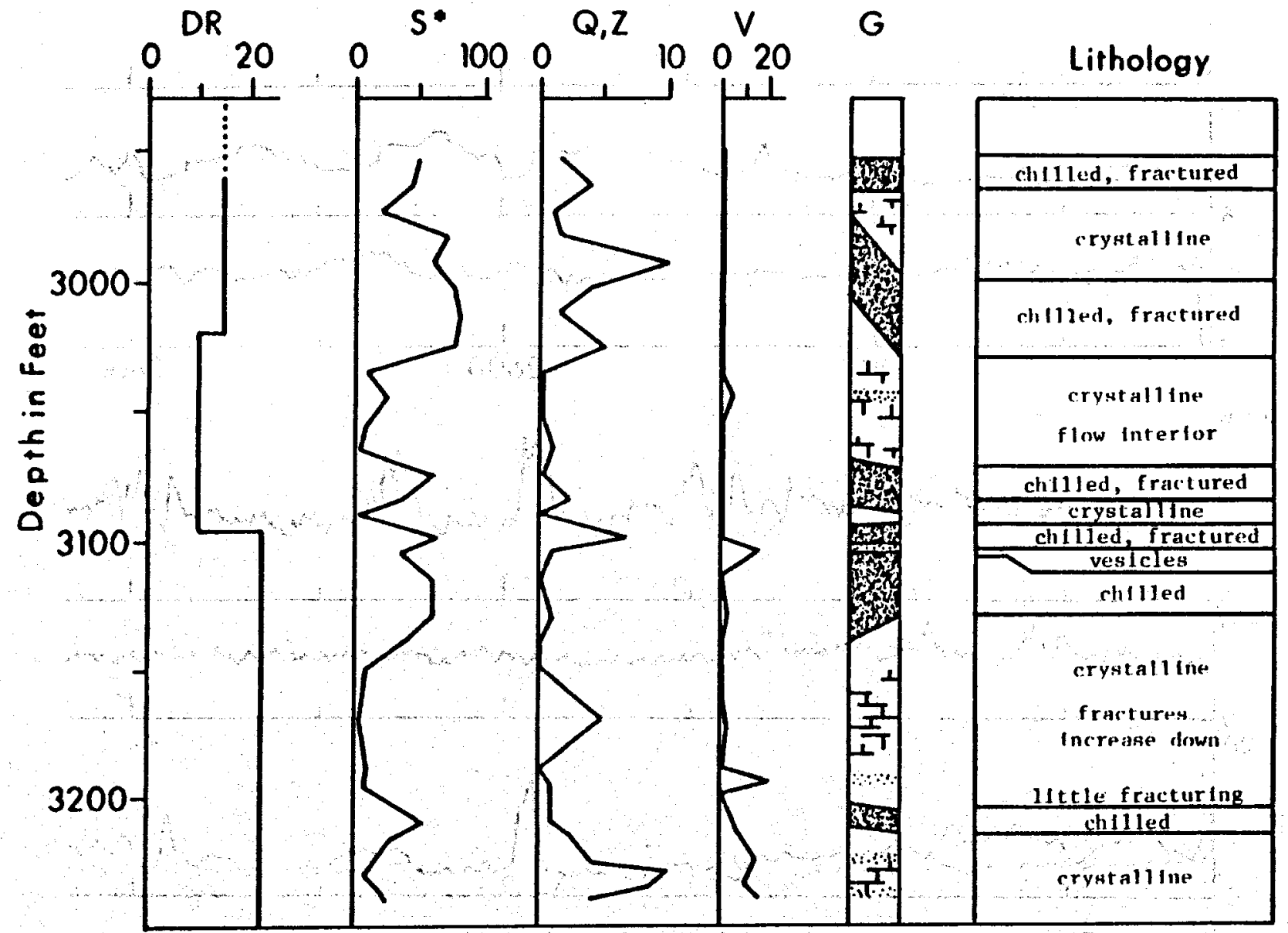

* RFM ININI: * REPRFSENTS GRAY, MICRIYGRYSTAIJ,INE TO GRYSTALIINE, BASAI.T GRADINC: INTO MICROIABBRO, IIF FIOW INIT INTFRIORS

POKTTE IS PRESENT IN TRACE AMUINTS IN AII. SAMPI.SS STUIIEN, CALCGTE IS ABSENT, EXCFPT AT 2963. - A SHORT PERIOI) UF I,OST (IRCOUIATION OCCURRED BFIWEEN 3060 and 3070 TEET.

Figure 3. Geologic section (G) drililng rate (DR), and volume percentages of dense, glassy black selvedge (S), fracture fllilings of quartz and zeolite $(Q, Z)$ and vesicles (V). Based on macro- and microscopic studies of sample cuttings by Daniel B. Palmiter. 

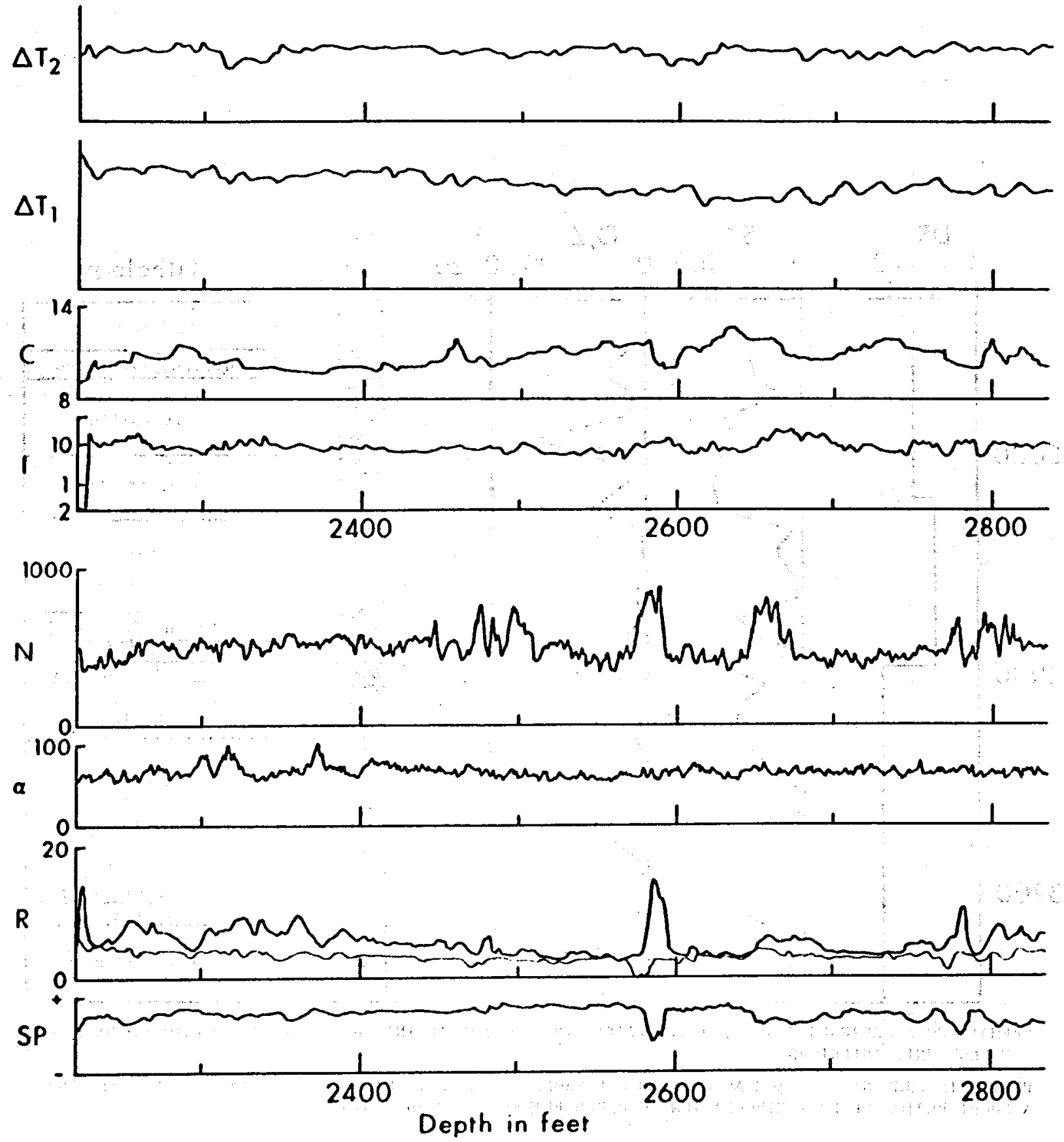

Figure 4. Self potential (SP), resistivity (R), gama ray ( $\gamma$ ) neutron (N), induction (I), caliper (C) and differential temperature $(\Delta T)$ logs from 2220 to 3450 (in uncased portion of $\mathrm{HGP}-\mathrm{A}$ well). 
$\Delta T_{2} \mathrm{Nm}_{1}$
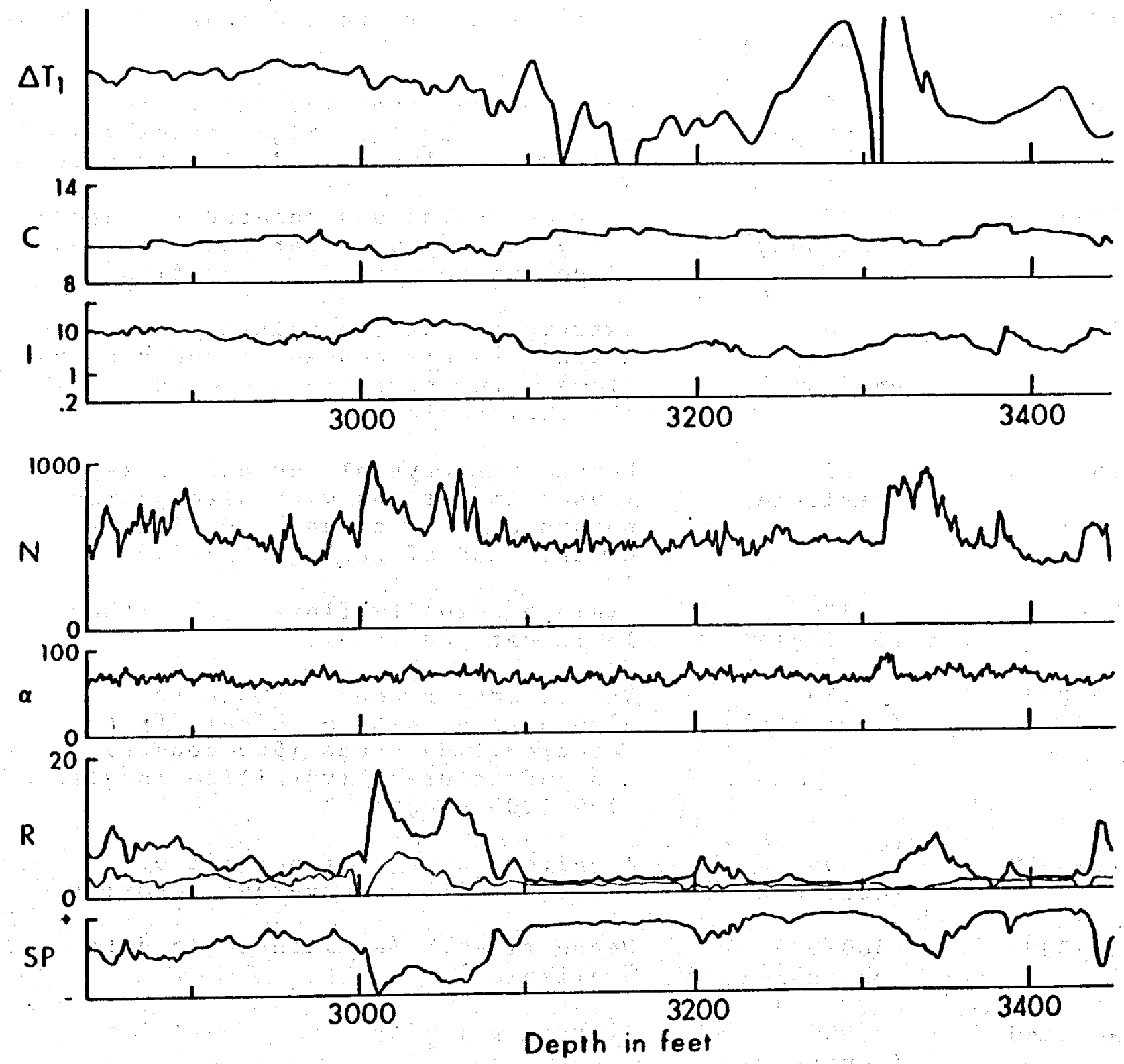

- Figure 4. (cont.) 
Table 2. Relationship of HGP-A neutron log count to geology and relative porosity.

\begin{tabular}{|c|c|c|}
\hline $\begin{array}{l}\text { Interval } \\
\quad(f t)\end{array}$ & $\begin{array}{l}\text { Count } \\
\text { (avg ) } \\
\text { API units }\end{array}$ & $\begin{array}{l}\text { Geologic interpretation } \\
\text { (based on logs and 1ithogic } \\
\text { columns, see Figs. } 1,2,3 \text { and } 4\end{array}$ \\
\hline $18-80$ & $\begin{array}{l}200 \\
(\operatorname{variab1e})\end{array}$ & Near surface weathered zone \\
\hline $80-950$ & $\begin{array}{c}150 \\
(\text { constant })\end{array}$ & $\begin{array}{l}\text { Low neutron count may partly re- } \\
\text { sult from casing. High porosity } \\
\text { related to clinker and cinder zones }\end{array}$ \\
\hline $950-1250$ & $\begin{array}{l}275 \\
(\operatorname{var} i a b l e)\end{array}$ & $\begin{array}{l}\text { Neutron variations related to inter- } \\
\text { fingering of vesicular pahoehoe and } \\
\text { cinder units with dense a flows }\end{array}$ \\
\hline $1250-1375$ & $\begin{array}{l}600 \\
(\text { highly } \\
\text { variable) }\end{array}$ & $\begin{array}{l}\text { Extreme variations related to alter- } \\
\text { nating, thinly bedded a and pahoehoe } \\
\text { flows. Low porosity associated with } \\
\text { altered basalt (?) }\end{array}$ \\
\hline $1375-2220$ & $\begin{array}{c}250 \\
(\operatorname{var} i a b 1 e)\end{array}$ & $\begin{array}{l}\text { Dense microcrystalline and glassy } \\
\text { (submarine) flows with alternating } \\
\text { porous beds of cinder and clinker } \\
\text { units. End of casing at } 2220 *\end{array}$ \\
\hline $2220-2950$ & $\begin{array}{l}500 \\
(\operatorname{variab1e})\end{array}$ & $\begin{array}{l}\text { Average porosity flows. (No litho- } \\
\text { logic data available) }\end{array}$ \\
\hline $2950-3070$ & $\begin{array}{l}750 \\
(\operatorname{variable})\end{array}$ & $\begin{array}{l}\text { Variations in count relate to } \\
\text { alternating units of highly frac- } \\
\text { tured chilled zones ( } 500 \text { counts) } \\
\text { and unfractured crystal1ine basalts } \\
\text { ( } 750-1000 \text { counts) }\end{array}$ \\
\hline $3070-3310$ & $\begin{array}{l}500 \\
(\text { constant })\end{array}$ & $\begin{array}{l}\text { A uniform zone of fractured or } \\
\text { vestcular flows. Average porosity. }\end{array}$ \\
\hline $3310-3390$ & $\begin{array}{l}500-800 \\
(\operatorname{variable})\end{array}$ & $\begin{array}{l}\text { Dense flows. (No lithologic data } \\
\text { available.) }\end{array}$ \\
\hline $3390-3440$ & $\begin{array}{l}500 \\
(\operatorname{constan} t)\end{array}$ & Average porosity \\
\hline
\end{tabular}

* The change in neutron count at 2220 feet (casing) from 250 to 500 counts indicates the equivalence of these values for average porosity. 
For example, the short normal $10 \mathrm{~g}$ is especially influenced by the mud cake and an invaded zone immediately adjacent to the borehole. It follows that for a high resistivity (fresh water) mud, the short normal log records resistivities higher than the medium normal $10 \mathrm{~g}$.

Values observed on the logs are generally not a true resistivity $\left(R_{t}\right)$. Readings are affected by the borehole size, drilling mud type, the depth to which the mud invades the formation, the uncontaminated zones and adjacent beds--for this reason $10 \mathrm{~g}$ values are called apparent resistivity $\left(R_{0}\right)$. Shapes of resistivity curves are also influenced by bed thickness relative to instrument spacing. Therefore, a quantitative evaluation of formation resistivity involves careful corrections of borehole and formation affects based on data from several different types of logs. In this preliminary study, limited time did not permit such detailed analysis.

As a generalization, resistivity of a formation is proportional to the resistivity of the fluid content. If the fluid resistivity is constant, observed variations on a $10 \mathrm{~g}$ are a measure of changes in porosity. Detailed log studies can yield values for such parameters as porosity, percentage of fluid saturation, cementation factor, and permeability. Again, analysis of these HGP-A logs was limited to estimates of relative changes in porosity.

An overall summary of the 16-inch conventional log (Figure 4) is presented in Table 3. Logs extend from the bottom of the casing $(2220$ feet) to 3445 feet. At that depth, well temperatures were about $120^{\circ} \mathrm{C}$ (Figures 5 and 6 ) and the sonde was pulled out.

Interpretation. Apparent resistivity $(16$-inch) on the HGP-A log decreases linearly with depth from an average 5 ohmmeters at 2220 feet to 1 ohm-meter below 3200 feet. A unit with 5 ohm-meters near the top of the well is interpreted to have similar properties to a 1 ohm-meter unit at depth. Such a linear decrease may result from a continuous mixing of nearsurface fresh water with increased brine content at depth, or it may be related to the increased temperature. Values from the resistivity log in general, correlate well with the electrical resistivity data obtained on the surface (Klein and Kauahikaua, 1975 ).

The 16-inch, and sometimes the 64-inch log, reveal several zones of high resistivity that are interpreted as dense flows of low porosity. This interpretation is supported by a comparison of resistivity and neutron logs. For example, the interval from 3000 to 3080 feet shows high values on both types of logs. Moreover, the 1ithologic column (Figure 3) lists an unfractured, crystalline flow for this same interval. other zones are listed in Table 3. Unfortunately, the surface 
12

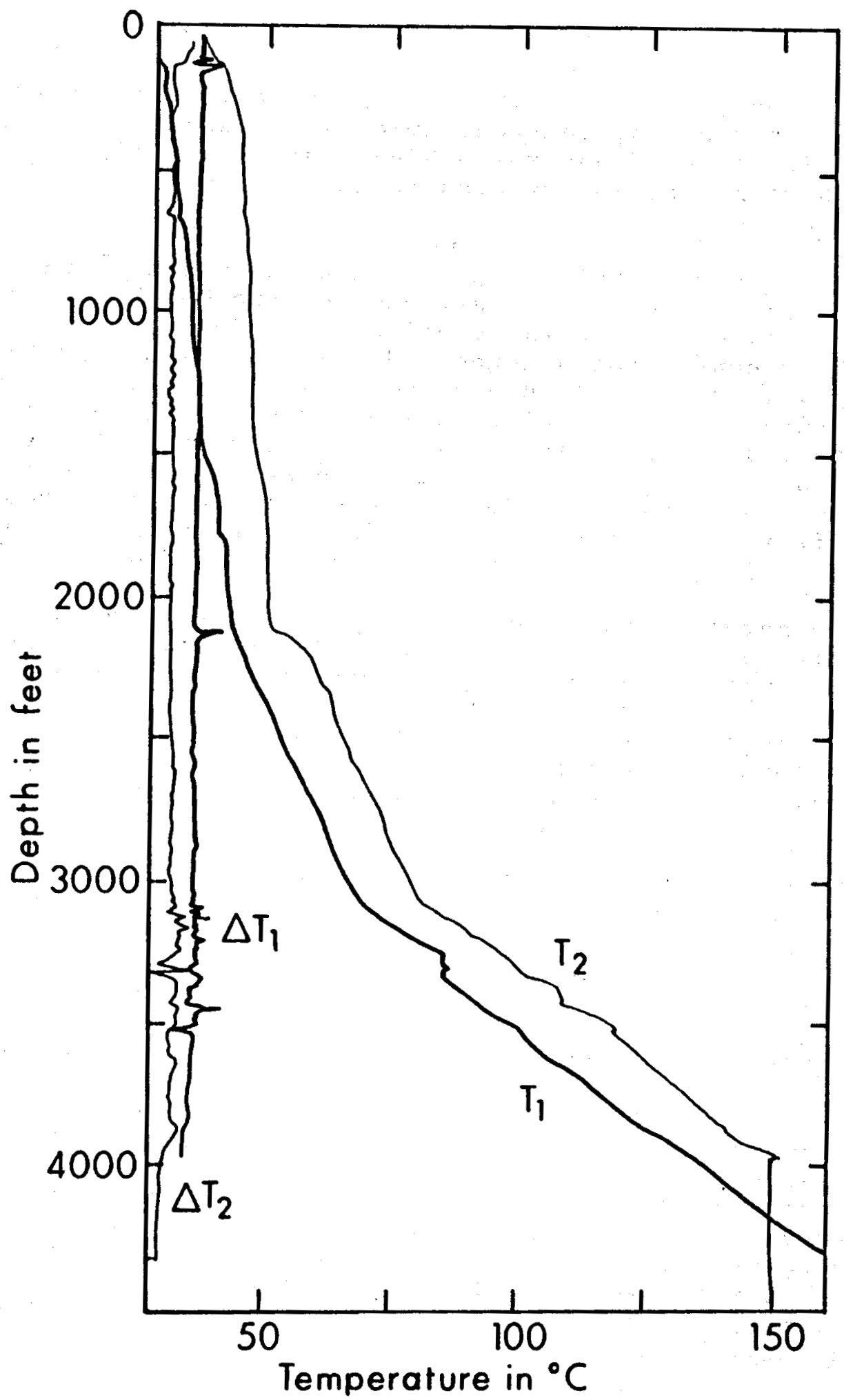

Figure 5. Continuous temperature logs (T) and temperature differentials $(\Delta T)$ for two separate runs at 12-hour intervals. $\Delta T_{1}$ and $T$ were recorded on $04-25-76$ at 1100 hours and ${ }^{1} \Delta \mathrm{T}_{2}$ and $\mathrm{T}_{2}$ on $04-25-76$ at 2300 hours. 


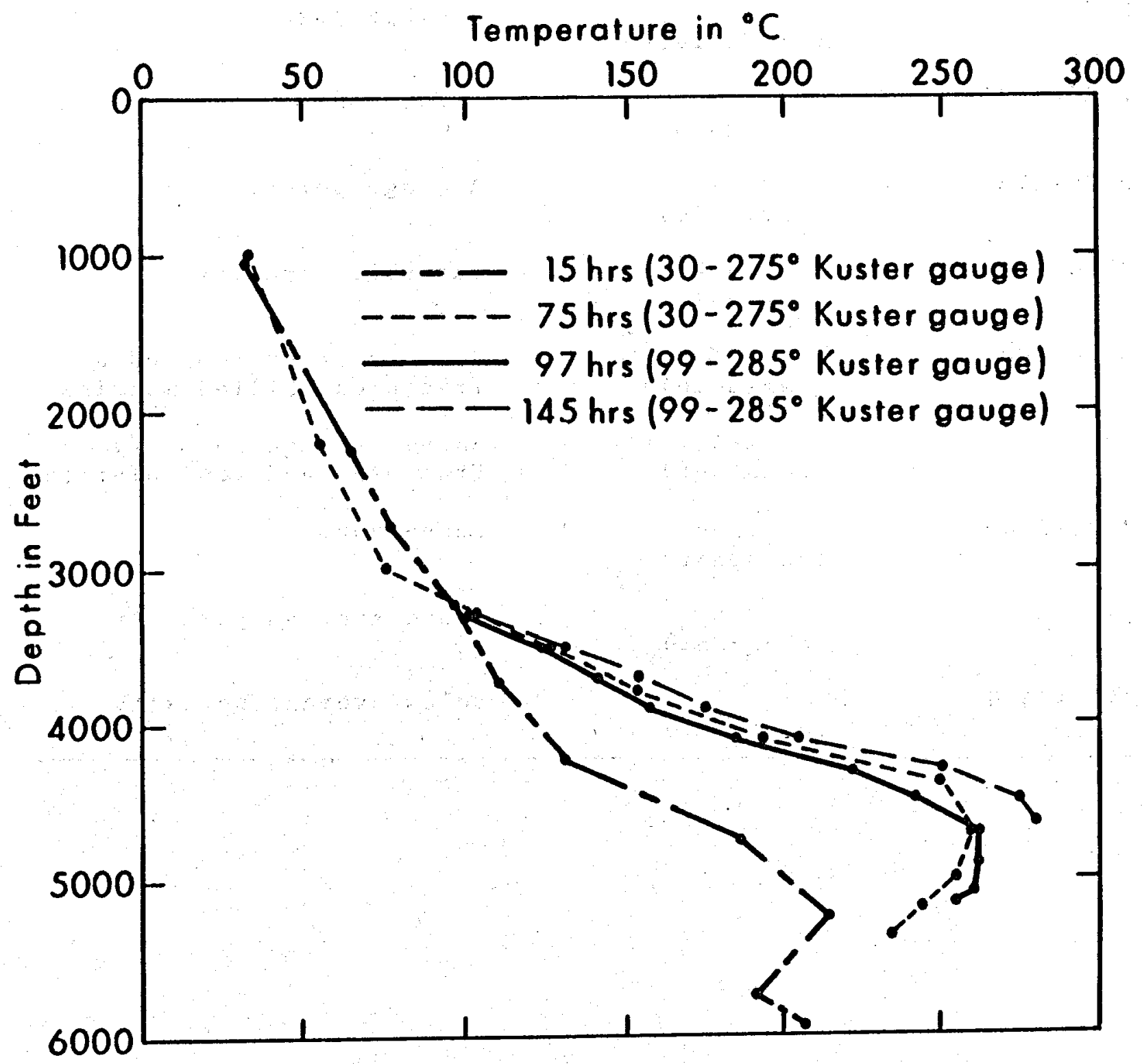

Figure 6. Kuster thermograph for four separate runs. 
Table 3. Relationship of HGP-A conventional resistivity logs to geology and relative porosity.

\begin{tabular}{|c|c|c|}
\hline $\begin{array}{l}\text { Interval } \\
\quad(f t)\end{array}$ & $\begin{array}{l}\text { Resistivity }(16-i n) \\
\text { (in ohm-meters) }\end{array}$ & $\begin{array}{l}\text { Geologic Interpretation } \\
\text { (based on Fig. } 3 \text { and } 4 \text { ) }\end{array}$ \\
\hline $2230-2400$ & $\begin{array}{c}4-8 \\
(\operatorname{variable})\end{array}$ & Below average porosity \\
\hline $2400-2580$ & $\begin{array}{c}2.5-5 \\
(1 \text { inear decrease) }\end{array}$ & Average porosity \\
\hline $2580-2600$ & (peak ${ }^{12}$ value) & Dense zone \\
\hline $2600-2780$ & $\begin{array}{c}2 \cdot 5-5 \\
(\operatorname{variable})\end{array}$ & Average porosity \\
\hline $2780-3000$ & $\begin{array}{c}2.5-8 \\
(\operatorname{variable})\end{array}$ & Variable porosity \\
\hline $3000-3080$ & $\begin{array}{c}5-15 \\
(\operatorname{variab} 1 e)\end{array}$ & $\begin{array}{l}\text { Dense zone surrounded by } \\
\text { fractured chilled margins }\end{array}$ \\
\hline $3080-3300$ & $\begin{array}{c}2-4 \\
(\operatorname{constan} t)\end{array}$ & $\begin{array}{l}\text { Above average porosity } \\
\text { Fractures and vesicularity }\end{array}$ \\
\hline $3300-3360$ & $\begin{array}{c}2 \cdot 5-6 \\
(\operatorname{constan} t)\end{array}$ & Dense. zone \\
\hline $3360-3440$ & $\begin{array}{c}2.4 \\
(\operatorname{constan} t)\end{array}$ & Above average porosity \\
\hline $3440-3450$ & $\begin{array}{c}7 \\
\text { (constant) }\end{array}$ & Below average porosity \\
\hline
\end{tabular}


resistivity measurements were unable to resolve any of these zones.

\section{Induction Logs}

Principles. Induction logging uses a high-frequency. alternating current to induce ground $100 p$ currents in the formation. These loops, in turn, create magnetic flelds measured by the sonde. The received magnetic fields represent a focused signal that minimizes the influence of the borehole and is designed for deep investigation of the surrounding formations. For this report the induction $10 \mathrm{~g}$ will presume to approximate the true resistivity $R_{t}$ far enough from the borehole to be unaffected by invasion.

Interpretation. The linear decrease in resistivity with depth observed in the conventional resistivity logs are not apparent in the induction $10 \mathrm{~g}$ (Figure 4). Instead, the resistivity averages almost 10 ohm-meters from 2220 to 3080 feet. There is a marked decrease in average resistivity below 3080 feet, varying from 2 to 5 ohm-meters. The decrease, also observed in the resistivity $10 \mathrm{~g}$, may be related to several different sources or to a combination of circumstances. The logs suggest that there is an increased overall porosity below 3080 feet. If so, the increased brine volume might cause the decrease in resistivity. There is also a suggestion of increased fracture permeability with movement of brine into the hole (see the discussion on temperature differential). Lithologic studies of cores and samples may confirm this increase in fracture porosity. The induction $\log$ is sufficiently similar to the conventional resistivity log that a tabled summary of the induction $\log$ is not included in this report.

\section{Self Potential Logs}

Principles. Thus far, the logs discussed in this report have been studied primarily to identify porosity variations. However, self potential logs are more useful in detecting permeability. SP logs record the potentlal at a moving electrode caused by electrochemical and electrokinetic origins, or both. If the SP results from electrochemical effects, a negative potential is observed for permeable formations (assuming the mud salinity is less than that of the formation water). Negative" SP results from electrokinetic effects if fluids flow from the borehole into the formations. According to Lao et a1. (1969), SP logs in Hawailan water wells were inconststent and complicated to Interpret. However, SP logs in the HGP-A we11 (drilled with fresh water mud) seem reliable and delineation of permeability zones appear feasible.

SP curves are most useful in detecting permeable beds by deflections from the average value associated with nonpermeable 
formations (the 'shale' line). The average posttion of the SP line is arbitrarily set by the log engineer and its value is not meaningful. Instead, it is the excursions from the shale line that identify the permeable zones.

Interpretation. The shape and amplitude of the SP curve depend on such factors as bed thickness, the formation resistivity, and the characteristics of the mud and mud filtrate in the invaded zone and borehole. Given such data it is possible to determine the resistivity of formation water (R) which, in turn, can be used to calculate porosity. Until more information is made available, analyses of the SP log from the HGP-A well are restricted to identification of permeable zones.

The SP $\log$ (Figure 4) shows a linear, positive deflection increasing from top to bottom (2220 to 3450). Superimposed on this gradient are negative deflections that are ldentified as possible zones of permeability. (Table 4). Future study of the temperature differential logs, in combination with the SP, may identify the zones of moving water.

\section{Gamma Ray Logs}

Principles. Gamma ray logs measure high energy electromagnetic waves emitted by naturally radioactive elements of uranium-radium, thorium, and the potassium isotopes. Because such elements tend to concentrate in shales and clays, gamma ray logs are most useful in sedimentary sequences. In basaltic rocks, percentages of radioactive minerals are ordinarily quite low and low gamma counts with only minor variations are expected. Nevertheless, the HGP-A well shows evidence of hydrothermal mineralization, weathering products, and pyritization. If potassium mineralization is concentrated along fracture zones, the gamma log may detect these permeable zones.

Interpretation. The Gamma ray $10 \mathrm{~g}$ of the HGP-A well extends from 20 to 3448 feet (Figure 1). Within the cased portion of the well (to $2220 \mathrm{ft}$ ), the average gamma count is 60 (API) counts, and only minor variations are observed. In the uncased portion, average counts increase slightly to 70 counts. It is not certain whether the observed variations in counts are instrumental or geologic in origin. In a spirit of optimism, we can associate increased gamma counts with concentrations of radioactive mineralization along fracture zones.

Increased gamma counts sometimes are observable immediately above and below dense, crystalline units. It is geologically reasonable to associate the tops and bottoms of dense units with either clinker zones or a type of fracturing along chilled margins. The source of mineralization along these fractures is unknown, but Table 5 summarizes empirical relationships of gamma count and geology. 
Table 4. Re1ationship of HGP-A self potential logs to possible zones of relative permeability. Analysis is based on correlation lithologies (Fig. 2 and 3 ) and SP logs (Fig. 4).

\begin{tabular}{|c|c|c|}
\hline $\begin{array}{l}\text { Interval } \\
(f t)\end{array}$ & $\begin{array}{c}\text { Self potential } \\
(\text { In } \mathrm{mV})\end{array}$ & Geologic interpretation* \\
\hline $2220-2580$ & Essentia11y constant & $\begin{array}{l}\text { Some minor variations in the } \\
\text { sp may be related to thin } \\
\text { permeable beds }\end{array}$ \\
\hline $2584-2596$ & $\begin{array}{l}\text { Negative deflection } \\
(-65 \mathrm{mV})\end{array}$ & $\begin{array}{l}\text { Thin permeable bed correlates } \\
\text { with dense zone. Fracture } \\
\text { porosity? }\end{array}$ \\
\hline $2596-3000$ & $\begin{array}{l}\text { Variable ( } \text { ( deflec- } \\
\text { tions) }\end{array}$ & $\begin{array}{l}\text { Thin permeable beds correlate } \\
\text { with dense units identified } \\
\text { on resistivity and neutron } \\
\text { logs }\end{array}$ \\
\hline $3000-3100$ & $\begin{array}{l}\text { Negative deflection } \\
\quad(-140 \mathrm{mV})\end{array}$ & $\begin{array}{l}\text { A dense crystalline bed with } \\
\text { fractured zones on the top } \\
\text { and bottom chilled zones. }\end{array}$ \\
\hline $3100-3450$ & $\begin{array}{l}\text { Essentially constant } \\
\text { (a few negative } \\
\text { deflections) }\end{array}$ & $\begin{array}{l}\text { Predominately porous zones } \\
\text { with some fractured perme- } \\
\text { ability }\end{array}$ \\
\hline
\end{tabular}

* The average non-permeable deflection (shale line) varies linearly from $+40 \mathrm{mV}$ near the top of the $10 \mathrm{~g}$ to $+100 \mathrm{mV}$ near the bottom ( 3450$)$. 
Table 5. Relationship of HGP-A gamma ray log count to possible zones of relative permeability. Analysis is based on correlation of 11thologies (Figures 2 and 3 ) and gamma ray and neutron logs (Figures 1 and 4)

\begin{tabular}{|c|c|c|}
\hline $\begin{array}{l}\text { Interval } \\
(\mathrm{ft})\end{array}$ & $\begin{array}{l}\text { Count } \\
(\text { Avg. API units) }\end{array}$ & Geologic interpretation \\
\hline $22-1160$ & $\begin{array}{c}60-65 \\
(\text { constant })\end{array}$ & No obvious correlations \\
\hline $1160-1215$ & $\begin{array}{c}55-70 \\
(\operatorname{variab1e})\end{array}$ & $\begin{array}{l}\text { Circulation losses and hydro- } \\
\text { thermal alteration products } \\
\text { suggest (fracture) permeability }\end{array}$ \\
\hline $1215-1835$ & $\begin{array}{l}60 \\
(\operatorname{constan} t)\end{array}$ & No obvious correlations \\
\hline $1835-1845$ & $\begin{array}{c}70-80 \\
\text { (maximum value) }\end{array}$ & Cinder and clinker zone \\
\hline $1845-2220$ & $\begin{array}{c}55-65 \\
(\text { constant) }\end{array}$ & $\begin{array}{l}\text { Glassy to microcrystalline } \\
\text { basalt. Neutron log shows } \\
\text { average porosity }\end{array}$ \\
\hline $2220-3452 *$ & $\begin{array}{c}60-70 \\
(\operatorname{variable})\end{array}$ & $\begin{array}{l}\text { No lithologic column available. } \\
\text { Neutron and resistivity logs } \\
\text { shows variable porosity (dense) } \\
\text { zones }\end{array}$ \\
\hline
\end{tabular}

*Interval includes zones of increased gamma ray count coincident with tops and bottoms of dense flows. One example is shown on Figure 4 at a depth of 3310-3320. The increased gamma count is just above a dense zone identified on the neutron $10 \mathrm{~g}$. 


\section{Caliper Logs}

Principles. Caliper logs are constructed with either twoor three-arm calipers to obtain diameter measurements of borehole size in inches. In this study, a two-arm caliper was used (Figure 4.) Because some geophysical logs are influenced by borehole size, caliper logs allow one to apply corrections for quantitative evaluations of porosity and permeability. Such corrections were not, however, applied in this report.

Interpretation. In Hawail, correlation has been made with zones of caving indicative of loose, permeable clinker zones (Lao et al., 1969). Moreover, a decrease in diameter may indicate the presence of a mud cake associated with permeable zones. The $10 \mathrm{~g}$ shows borehole sizes from $9-1 / 2$ to $12-1 / 2$ inches (the bit size was 7-5/8 inches below $2220 \mathrm{ft}$ ). There is good correlation between the borehole size and the extremely dense units, but only fair correlation for the more subtle variations. The caliper values are not tabled here, but their role in total interpretation is mentioned in a later section dealing with integrated analysis of all logs.

\section{Temperature Logs}

Principles. Temperature logs measure the absolute values of temperature of the mud in the borehole. In this report, two devices were used: a thermistor and a metallic expansion device (Kuster thermograph). The thermistor type yields a continuous readout but is only operable to temperatures of about $150^{\circ} \mathrm{C}$ (Figure 5). The Kuster thermograph is operable to much higher temperature (Figure 6) but gives only point values (versus continuous readouts). Temperature differentials were recorded on a continuous readout instrument, but the gradients appear unreliable and are not extensively discussed in the report.

Interpretation. The continuous temperature $10 \mathrm{~g}$ for HGP-A (Figure 5) was run at two separate times, 12 hours apart, with an approximate increase of 12 to $16^{\circ} \mathrm{C}$ as the we 11 heated up. A sudden increase in temperature gradient to $.025^{\circ} \mathrm{C} / \mathrm{ft}$ is ob-. served below the casing ( 2200 to 3200 feet). This is followed by another change in gradient to $.073^{\circ} \mathrm{C} / \mathrm{ft}$ in the interval from 3200 to 4000 feet, at which point the sondes were withdrawn. Moreover, the temperature differential curve shows rapid gradient fluctuations in the $3100-$ to 3500 - foot interval, possibly identifying a zone of fluid influx in that approximate interval.

The Kuster thermograph (Figure 6) shows the same increase in gradient below 3000 feet, although the absolute value of $.125^{\circ} \mathrm{C} / \mathrm{ft}$ is higher. Because the thermistor sensitivity decreases above $100^{\circ} \mathrm{C}$, the Kuster values are considered more reliable. Four separate logs were run with the kuster to 
monitor the increased temperatures, with only minor differences observed after 75 hours. The plots do show a temperature inversion below 4500 feet, suggestive of an influx of cooler fluids. Bottom hole monitors now have recorded new values as high as $357^{\circ} \mathrm{C}$, making the HGP-A one of the hottest geothermal wells in the world.

\section{Driling Rates}

Princlples. Drilling rates are recorded on a dally log showing time and foot-by-foot penetration of the drill. The recording device simultaneously registers vertical driling pressure and torque exerted under control of the driller. Drili site observers expressed some skepticism about the reliability of the drill pressure and torque data (both of these devices were unfamiliar to the operator). Therefore, analysis in this report excludes these two data items.

Interpretation. Drilling rates were converted from the daily log to a histogram (Figure 7). A visual judgment was first made to select intervals of time during which the rate of penetration was approximately constant. Computations in feet per hour then constituted one "block" of the histogram. Some correlation of drilling rates with porosity and permeability are apparent and are summarized in the concluding section.

\section{INTEGRATED ANALYSIS OF PRINCIPLE LOGS}

Interpretation of any single $\log$ is always suspect. This is especially true in the HGP-A well where instrument characteristics and calibrations were not always available. If one analyzes a group of logs simultaneously, it is possible to interpret the data with some degree of confidence. This type. of integrated analysis is presented below for the interval from 3000 to 3400 feet. Presumably, similar analyses could be done for other zones.

3000 to 3100 feet (Figure 8). Resistivity and neutron logs show large positive readings indicating an interval of low porosity, with extremely dense zones at the top and bottom. Lithology studies substantiate a thick, dense flow with fractured, chilled margins on top and bottom (Figure 3). other logs substantiate the dense zone. For example, the induction logs show large positive resistivity. Also, the drilling rate decreases from $20 \mathrm{ft} / \mathrm{hr}$ in a porous zone $(3100$ to 3200$)$ to $10 \mathrm{ft} / \mathrm{hr}$ in the 3000 to 3100 foot interval (Figure 7).

Despite the low porosity, there is strong evidence of some permeability in this same interval. The SP log (Figure 8) shows an overall negative deflection, and maximum negative values 


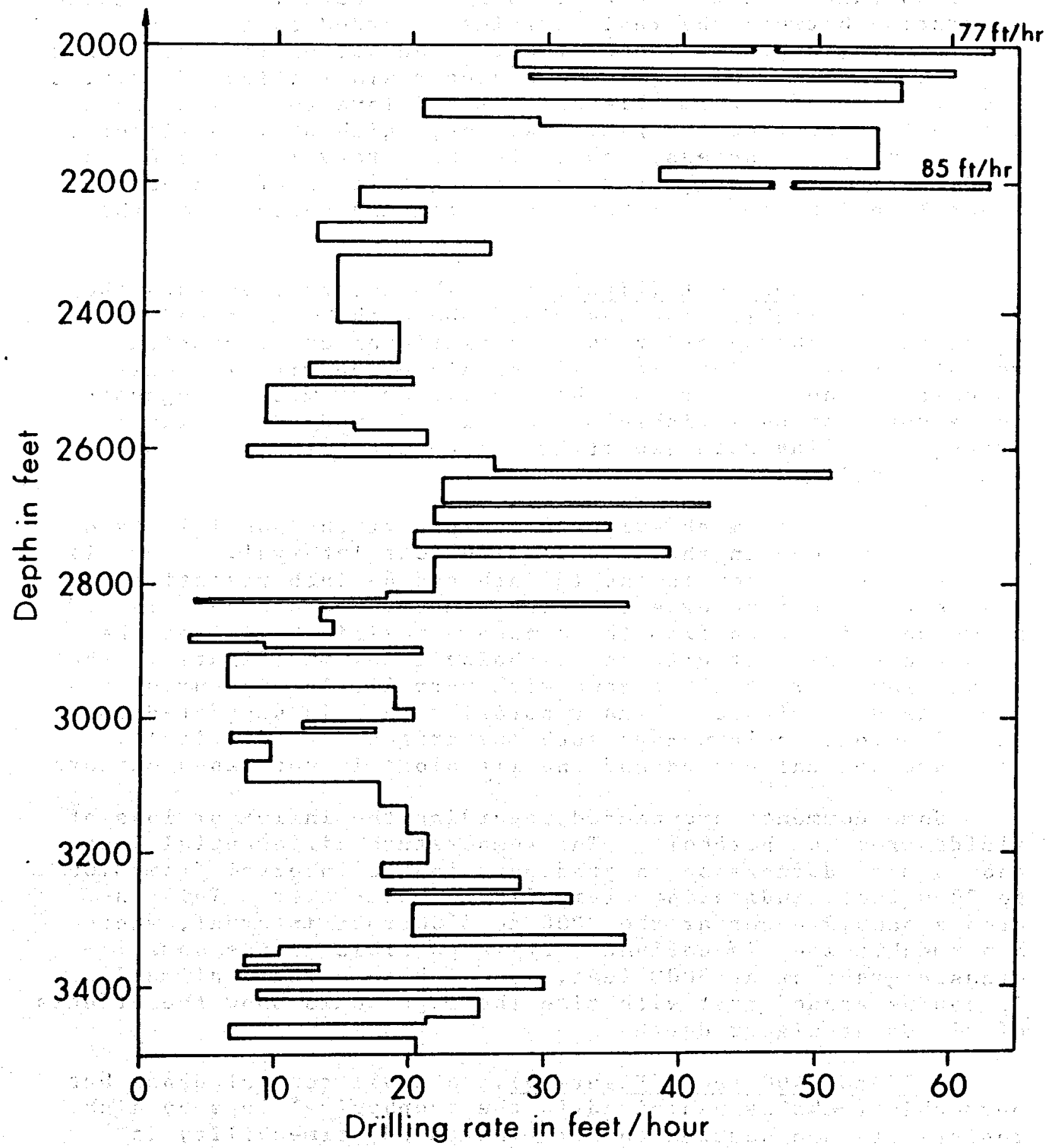

Figure:7. HGP-A drilling rate in feet per hour for the 2000- to 3500-foot interval. 
again peak at the top and bottom of the interval. Moreover, the caliper $\log$ shows a decrease in diameter, indicative of the development of a mud cake opposite a permeable zone. Comparison of the 16-inch and 64-inch resistivity logs provides still another clue to the permeability. There is a noticeable separation between the resistivities recorded by the two instruments, especailly near the top and bottom fracture zones. Such separations for shallow and deep resistivities identifies the presence of a permeable zone of mud invasion. The final evidence comes from the gamma ray log, which shows a slightly, but definitely, increased count in the interval from 3000 to 3100 feet. It is suggested that concentration of radioactive mineralization along a fractured system may account for the Increase.

3100 to 3200 feet (Figure 8 ). The interval beneath the dense but permeable zone described above shows a marked contrast in $\log$ characteristics. Conventional and induction resistivities are low, identifying a section with increased porosity. The caliper $10 \mathrm{~g}$ shows a larger diameter, suggesting a more porous (friable?) zone with no mud cake. The increased drilling rate $(20 \mathrm{ft} / \mathrm{hr})$ is consistent with this interpretation.

There is not much evidence to support the possibility of a permeable zone in the 3100 to 3200 foot interval. There is no marked separation in the 16-inch and 64-inch resistivity logs such as can be expected with a mud invaded zone. The SP shows no deflection from the standard position. All of the logs are consistent with the lithologic column (Figure 7) that identifies a crystalline zone with very little fracturing. The logs do indicate a higher porosity than is suggested on the lithologic column--but such comparisons are difficult. The logs are not calibrated and the lithology is not based on cores.

Some comments are needed regarding the influx or loss of fluids from the borehole. The temperature differential logs show a marked increase in gradients in the interval from 3100 to 3200 feet, indicating fluid flow of hot water. This increase should occur at the 3000 to 3100 foot interval, where a permeable zone is defined. It is possible to see some increased gradient at 3000 feet, and with some rationalization it can be argued that with time the logs would show the effects of fluids at higher depths.

3300 to 3400 feet (Figure 9). A small zone of dense but permeable rocks is exhibited in the geophysical logs by high resistivity and neutron count. Increased permeability is marked by negative SP deflection, a decreased diameter on the caliper log, and wide separation of resistivities for the 16-inch and 64-inch logs. The gamma ray $10 \mathrm{~g}$ shows a strong increase at the top of the interval (at 3310 to $3320 \mathrm{feet}$ ), suggesting a fracture system with mineralization. An extreme 

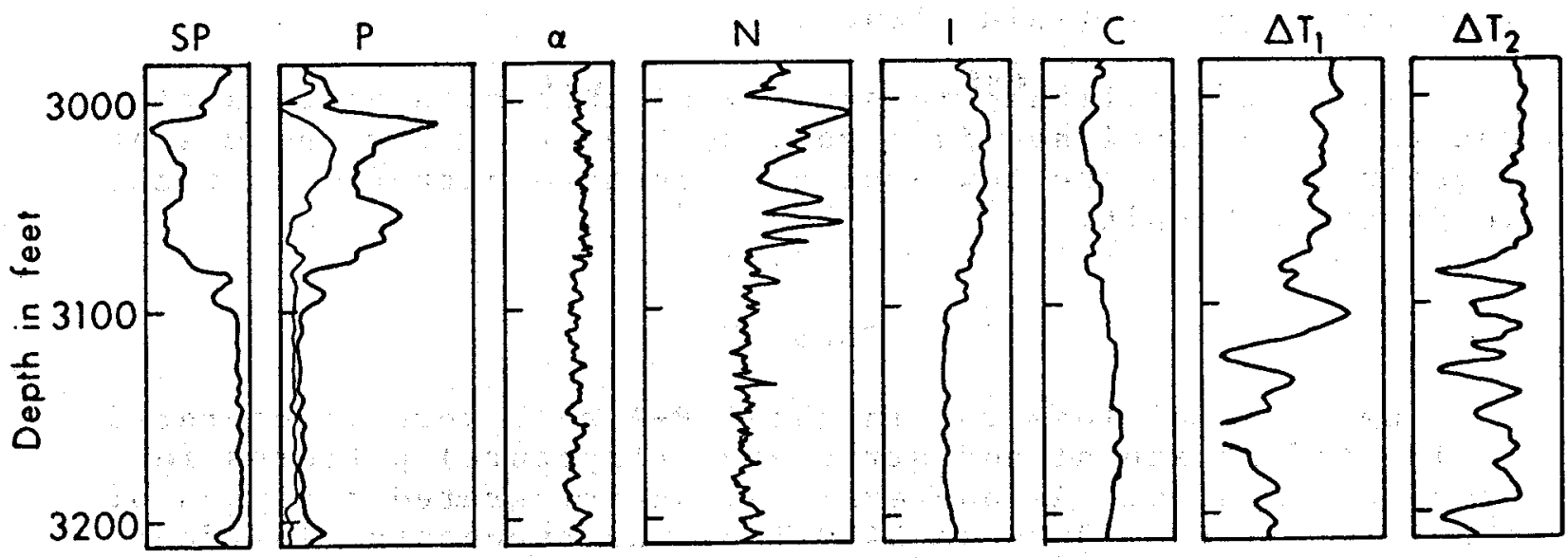

Figure 8. Geophysical logs used for integrated analyses of porous and permeable zones from 3000 to 3200 feet (See Figure 4 caption to identify headings).
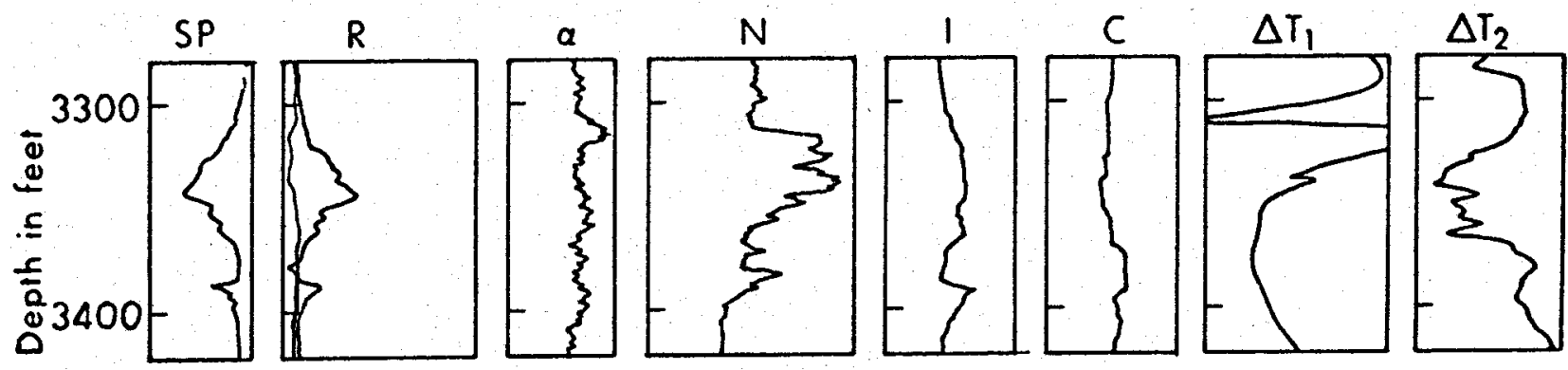

Figure 9. Geophysical logs used for integrated analyses of porous and permeable zones from 3300 to 3400 feet. 
temperature gradient at this same zone at the top of the interval suggests fluid flow.

There is no lithlogic summary of this zone at this time and the above analyses is a good control test for the use of logs in defining the textural and fracture patterns of rocks in Hawailan basalt.

\section{CONCLUSIONS}

Geophysical logs run in the HGP-A well were interpreted to identify textural and structural (fracture) patterns in Hawailian basalts. As one example, an integrated analyses of the interval from 3000 to 3400 feet was successful in 1dentifying a permeable zone with fluid influx. Therefore, development of specialized tools to operate at higher temperatures would be invaluable in the analysis of deep geothermal wells. The results presented in this study support the suggestion that future wells be logged to identify possible zones of production.

\section{ACKNOWLEDGMENTS}

I thank A. S. Furumoto and C. E. Helsley for their support in completion of this project. Frank Peterson, Gordon Macdonald, and Ralph Moberly provided technical assistance. Daniel Palmiter's lithologic logs were essential for the final analyses. 


\section{REFERENCES}

Furumoto, A. S., G. A. Macdonald, M. Druecker, and P. F. Fan, 1977. Preliminary Studies for Geothermal Exploration in Hawaii, 1973-1975. Geothermal Resources Exploration in Hawaii: No. 1 , HIG Report $75-5,55$ pp

Keller, G. V., C. K. Skokan, J. J. Skokan, J. Daniels, J. P. Kauahikaua, D. P. Klein, and C. J. Zablocki, 1977. Geoelectric Studies of the East Rift, Kilauea Volcano, Hawail Island. Geothermal Resources No. 3, HIG Report 77-15, $195 \mathrm{pp}$

Klein, D. P. and J. P. Kauahikaua, 1975. Geoelectric and Geothermal Exploration on Hawail Island. Preliminary Results: Geothermal Resources Exploration in Hawaii: No. 2 , HIG Report $75-6,23 \mathrm{pp}$

Kroopnick, P. M., R. W. Buddemeier, D. Thomas, L. S. Lau, and D. Bills, 1978. Hydrology and Geochemistry of a Hawailan Geotherma1 Sysaem: HGP-A Geothermal Resources Exploration in Hawail: No. 4, HIG Report 78-6, 64 pp

Lao, C., F. L. Peterson, and D. C. Cox, 1969. Application of Electric Well Logging and other well logging Methods in Hawaii. Water Resources Research Center, Tech. Report No. $21,108 \mathrm{PP}$

Peterson, F. L., 1974. Neutron Well Logging in Hawail. Water Resources Research Center, Tech. Report No. 75,42 pp

Peterson, F. L. and M. M. Segal, 1974. Determining Porosity with Neutron Logs from Hawailan Basaltic Aquifers. Water Resources Research Center, Tech. Report No. 80,37 pp

Schlumberger, 1969a. Log Interpretation Principles. Documented by Schlumberger Limited, New York, N. Y., 110 pp

Schlumberger, $1969 \mathrm{~b}$. Log Interpretation Charts. Documented by Schlumberger Limited, New York, N. Y., 76 pp

Zablock1, C. J., R. I. Tiliing, D. W. Peterson, R. L. Christensen, G. V. Keller, and J. C. Murray, 1974. A deep research drill hole at the summit of an active volcano, Kilauea, Hawail. Geophys. Res. Lett. v. 1 , no. 7, p. 323-326. 